\title{
Chemical and Physical Characterization of Peanut Powder Extracts
}

\author{
Luzia Marcia de Melo Silva ${ }^{1}$, Francisco de Assis Cardoso Almeida ${ }^{2}$, Francinalva Cordeiro de Sousa ${ }^{1}$, \\ Deise Souza de Castro ${ }^{2}$, Inácia dos Santos Moreira ${ }^{2}$, Jacinete Pereira Lima ${ }^{2} \&$ Acácio Figueiredo Neto ${ }^{3}$ \\ ${ }^{1}$ Federal Institute of Alagoas, Campus Murici, AL, Brazil \\ ${ }^{2}$ Federal University of Campina Grande, Campus I, PB, Brazil \\ ${ }^{3}$ Federal University of San Francisco Valley, Engineering Campus, Juazeiro, Bahia, Brazil \\ Correspondence: Acácio Figueiredo Neto, Department of agricultural engineering, Juazeiro, Bahia, CEP \\ 48902-300, Brazil. Tel: 55-74-2102-7621. E-mail: acacio.figueiredo@univasf.edu.br
}

$\begin{array}{ll}\text { Received: December 19, } 2017 & \text { Accepted: January 24, } 2018 \quad \text { Online Published: March 15, } 2018 \\ \text { doi:10.5539/jas.v10n4p323 } & \text { URL: https://doi.org/10.5539/jas.v10n4p323 }\end{array}$

The research is financed by CNPq.

\begin{abstract}
The production of lyophilized foods is a market with great growth potential, for providing important preservation characteristics, such as stability at ambient temperature, versatility of the product and preservation of the chemical compounds. Given the functional effects of peanut powder extracts, this study aimed to quantify the bioactive compounds and determine physical and chemical characteristics, comparing samples with and without skin. After obtaining the aqueous peanut extract the samples were frozen at $-18{ }^{\circ} \mathrm{C}$ for $24 \mathrm{~h}$. The formulated extracts were dried in a benchtop lyophilizer operating at temperature of $-55^{\circ} \mathrm{C}$ for a period of 48 hours. The powder extracts were disintegrated in a multiprocessor for 30 seconds and the samples were physically and chemically evaluated. The powder extracts were classified as non-hygroscopic, exhibiting poor fluidity and intermediate cohesiveness in samples with skin, and high cohesiveness in samples without skin. The powders showed agglomerated particles, with irregular and non-uniform shape. Potassium was the mineral found in largest amounts, as well as oleic and linoleic fatty acids. The particles of the powders exhibit a spherical shape, showing the presence of amorphous surfaces, in which there is no repetition of geometric forms. The peanut powder extracts are classified as non-hygroscopic, have poor fluidity, intermediate cohesiveness in samples with skin and high cohesiveness in samples without skin.
\end{abstract}

Keywords: Arachis hypogaea L., plant extracts, bioactive compounds, characterization

\section{Introduction}

Foods of vegetable origin constitute one of the main sources of bioactive compounds, with functional properties. According to Silva et al. (2012), the main antioxidants in plants are vitamins C and E, carotenoids and phenolic compounds, especially flavonoids. The amount and profile of these phytochemicals vary depending on type, cultivar or maturation level of the plant, as well as on the edaphoclimatic conditions of the cultivation (Freire et al., 2012).

Peanut is characterized as a functional food, due to the large amount of vitamins and minerals, for being rich in unsaturated fatty acids, particularly oleic and linoleic, and poor in saturated fatty acids, besides being an important source of vegetable protein. Its consumption is related to the reduction of diseases such as cancer, Alzheimer, cataract and Parkinson. These effects are attributed to the antioxidant properties of the bioactive compounds (Ayala-Zavala et al., 2011).

In food conservation, lyophilization stands out for preserving mainly the bioactive compounds and nutritional components, preserving the characteristic aroma and taste of the natural products, due to the conservation of the volatile aromatic compounds. This method favors the stability of the product stored at ambient temperature and significantly reduces its weight and volume, allowing the reduction in the costs with packages, storage and transport.

Studies have been conducted to expand the development of new products, combined with the use of new production techniques, because the health-diet binomial represents a new paradigm in the study on foods. Rosa 
and Cougo (2014), Juliano et al. (2014) and De-Melo (2016) demonstrate in their studies the advantages of lyophilization for the preservation of bioactive compounds and nutritional components in comparison to traditional drying methods. This fact is explained by the low temperature at which the entire process is conducted, which significantly reduces the alterations in the morphology of the initial product.

Assuming the particularity of each product, physical characteristics and chemical composition are essential for the adequate development of processes and simulations that aim to improve the production system of the peanut crop and its by-products. The challenge is to maintain the oxidative stability during the marketing chain, against extrinsic factors, including temperature, oxygen availability, light exposure and relative humidity, to preserve chemical, microbiological and sensory quality (Martín et al., 2016).

Araújo et al. (2014), evaluating the physical properties of peanut grains, claim that these characteristics are of great importance for the correct management of this crop, to minimize the production costs for higher competitiveness and maintenance of product quality.

Given the functional qualities of peanut powder extracts, this study aimed to quantify bioactive compounds and determine physical and chemical characteristics of the product, comparing samples with and without skin.

\section{Materials and Methods}

The experiments were conducted at the Laboratory of Processing and Storage of Agricultural Products (LAPPA), of the Academic Unit of Agricultural Engineering (UAEAg) and at the Laboratory of Chemistry and Biomass (LQB), both at the Federal University of Campina Grande (UFCG), Campina Grande, Paraíba, Brazil.

\subsection{Obtaining Peanut Powder Extract}

The peanut produced in the semi-arid region of northeastern Brazil was harvested, processed and cleaned to be taken to the laboratory. After natural drying at $40{ }^{\circ} \mathrm{C}$ and $28 \%$ relative humidity, the beans were dried and prepared for processing. Initially, $200 \mathrm{~mL}$ of the aqueous extract of peanut with and without skin, obtained at the 1:2 proportion (peanut:water), was placed in plastic polyethylene bowls-GN $1 / 2-200 \mathrm{~mm}$ and subjected to freezing through the direct contact of the samples with the cooled environment in a freezer at $-18{ }^{\circ} \mathrm{C}$, for $24 \mathrm{~h}$. Later, the formulated extracts were subjected to lyophilization at temperature of $(-55 \pm 3){ }^{\circ} \mathrm{C}$, for $48 \mathrm{~h}$, with final absolute pressure of $6.0 \mathrm{kPa}$. After the lyophilization process, the formulated peanut powder extracts were disintegrated in a multiprocessor for 30 seconds and the samples were chemically and physically evaluated.

\subsection{Determination of Bioactive Compounds}

Peanut powder extract samples were chemically characterized for the parameters: total phenolics (mg GAE $\mathrm{g}^{-1}$ ), antioxidant through the ABTS method ( $\mu$ mol TEAC g ${ }^{-1}$ ) and total flavonoids $\left(\mathrm{mg} \mathrm{CE} \mathrm{g}^{-1}\right)$.

\subsection{Total Phenolics}

The total phenolics contents were determined through the Folin-Ciocalteau method described by Nóbrega et al. (2014), using gallic acid as standard. The extracts were prepared through the dilution of $1.0 \mathrm{~g}$ of sample in $50 \mathrm{~mL}$ of distilled water and left at rest for $1 \mathrm{~h}$. A $50-\mu \mathrm{L}$ aliquot of the extract was transferred to a test tube and mixed with $2075 \mu \mathrm{L}$ of water and $125 \mu \mathrm{L}$ of the Folin-Ciocalteau reagent. The mixture remained at rest for 5 minutes and, immediately after, received $250 \mu \mathrm{L}$ of $20 \%$ sodium carbonate, followed by agitation and rest in a heated bath at $40{ }^{\circ} \mathrm{C}$, for 30 minutes. The calculations made in the determination of phenolic compounds used a standard curve with gallic acid, with readings in spectrophotometer at $765 \mathrm{~nm}$ and results expressed in milligrams of gallic acid equivalent (GAE) per gram of fresh weight of the sample (mg GAE g ${ }^{-1}$ sample).

\subsection{Antioxidant Activity through the ABTS Method}

The antioxidant capacity was determined using the ABTS [2,2-azino-bis-(3-ethylbenzothiazolin-6-sulfonic acid)] free radical-scavenging method, according to Rufino et al. (2010). The ABTS radical was formed by the reaction of the $7 \mathrm{mM}$ ABTS solution with a solution of $140 \mathrm{mM}$ potassium persulfate, incubated at ambient temperature in the dark for 16 hours and, immediately after, diluted in ethanol until absorbance of $(0.70 \pm 0.05) \mathrm{nm}$ at $734 \mathrm{~nm}$. The antioxidant capacity of the peanut powder extract was estimated using a mixture of $30 \mu \mathrm{L}$ of the extract with $3.0 \mathrm{~mL}$ of the ABTS radical. The reading was taken after 6 minutes of reaction in UV-VIS spectrophotometer (AGILENT 8453), using quartz cuvettes at the wavelength of $734 \mathrm{~nm}$ and ethanol as the standard. The calculations made in the determination of antioxidant activity used a standard curve of Trolox, previously established. The results were expressed in $\mu \mathrm{M}$ Trolox.g-1 extract. 


\subsection{Total Flavonoids}

The flavonoids were determined according to the methodology described by Woisky and Salatino (1998). Approximately $1.0 \mathrm{~mL}$ of the 1:10 dilution (peanut powder extract:methanol) was placed in a $5-\mathrm{mL}$ flask and mixed with $0.1 \mathrm{~mL}$ of the solution of $5 \%$ aluminum chloride and methanol until the measurement mark, with later homogenization and storage in a dark environment for 30 minutes. Readings were performed in a UV-VIS spectrophotometer (AGILENT 8453), using quartz cuvettes at the wavelength of $425 \mathrm{~nm}$. The flavonoids content was calculated using a calibration curve with catechin in the interval of 4 to $12 \mathrm{mg} \mathrm{mL}^{-1}$. The results were expressed in milligrams of catechin equivalent $\mathrm{g}^{-1}$ of sample.

\subsection{Physical and Chemical Characterization of the Powder Extracts}

The peanut powder extract samples were physically and chemically characterized for the parameters: wettability $\left(\mathrm{g} \mathrm{s}^{-1}\right)$, hygroscopicity (\%), apparent density $\left(\mathrm{g} \mathrm{mL}^{-1}\right)$, compact density $\left(\mathrm{g} \mathrm{mL}^{-1}\right)$, Carr index (\%), Hausner ratio, morphology of powder particles, ashes (\%), mineral composition ( $\mathrm{K}, \mathrm{P}, \mathrm{Mg}, \mathrm{Ca}, \mathrm{Si}, \mathrm{Zn}, \mathrm{Fe}, \mathrm{Mn}, \mathrm{S}, \mathrm{Rb}, \mathrm{Cu}, \mathrm{Ni}$, $\mathrm{Sr})(\%)$ and fatty acids (mg $100 \mathrm{~g}^{-1}$ of lipids).

\subsubsection{Wettability}

The wettability was determined according to the static method proposed by Ceballos et al. (2012).

A fixed amount of powder $(1 \mathrm{~g})$ was weighed and placed on a glass slide, situated $1 \mathrm{~cm}$ above the surface of the liquid (distilled water) at $25^{\circ} \mathrm{C}$, in a cubic container (transverse area $=25 \mathrm{~cm}^{2}$ ). The glass slide was then rapidly removed, causing to powder to fall on the surface of the water in the container. The time necessary for all particles to wet was visually determined and recorded with a chronometer. The wettability was calculated using Equation (1):

$$
\mathrm{W}=\mathrm{N} / \mathrm{t}
$$

where, W: wettability, $\mathrm{g} \mathrm{s}^{-1}$; $\mathrm{N}$ : mass of the sample, g; t: time, $\mathrm{s}$.

\subsubsection{Hygroscopicity}

Hygroscopicity was determined through the method proposed by Goula and Adamopoulos (2010), with some modifications. The powder samples $( \pm 1 \mathrm{~g})$ were weighed in glass capsules, placed in a hermetic container with a $\mathrm{NaCl}$-saturated solution (relative humidity of $75.29 \%$ ) at $25^{\circ} \mathrm{C}$ for seven days, with subsequent weighing of the powders. Hygroscopicity was calculated using Equation (2):

$$
\mathrm{H}=\mathrm{X} /(\mathrm{U} \cdot \mathrm{a}) \times 100
$$

where, H: hygroscopicity, \%; X: absorbed water mass, g; U: water content of the powder on dry basis, $\mathrm{g} \mathrm{g}^{-1}$; a: mass of the sample, $g$.

\subsubsection{Apparent Density}

Apparent density was determined according to the method used by Caparino et al. (2012), with some modifications, in which $8 \mathrm{~g}$ of the peanut powder extract were weighed in a $5-\mathrm{mL}$ graduated cylinder, without compaction, to determine the total volume occupied by the solid. The apparent density was calculated using Equation (3):

$$
\rho \mathrm{a}=\mathrm{ms} / \mathrm{Vt}
$$

where, $\rho$ a: apparent density, $\mathrm{g} \mathrm{mL}^{-1}$; ms: mass of the solid, g; Vt: total volume, $\mathrm{mL}$.

\subsubsection{Compact Density}

Compact density was determined by weighing a mass of peanut powder extract until completing a 5-mL graduated cylinder. The compact density was determined using the powder mass contained in the cylinder after being hand-tapped 50 times on the surface of the bench from a height of $10 \mathrm{~cm}$ (Tonon et al., 2013), and calculated using Equation (4):

$$
\rho \mathrm{c}=\mathrm{ms} / \mathrm{Vc}
$$

where, $\rho c$ : compact density, $\mathrm{g} \mathrm{mL}^{-1}$; ms: mass of the solid, g; Vc: volume of the solid after compaction, $\mathrm{mL}$.

\subsubsection{Carr Index}

The Carr index (CI) is a simple method to indirectly evaluate the flowing properties of powders through the comparison between the apparent density ( $\rho \mathrm{a})$ and the compact density $(\rho \mathrm{c})$ of the powder, which can be calculated with the Equation (5):

$$
\mathrm{CI}=(\rho \mathrm{c}-\rho \mathrm{a}) / \rho \mathrm{c} \times 100
$$




\subsubsection{Hausner Ratio}

The Hausner ratio (HR) is used to indirectly evaluate the flowing properties of powders and is determined based on the apparent density ( $\rho \mathrm{a})$ and compact density ( $\rho c$ ), according to the methodology of Hausner (1967), in which the factor is correlated with the fluidity of a powder or granulated material, calculated using Equation (6):

$$
\mathrm{HF}=\rho \mathrm{c} / \rho \mathrm{a}
$$

\subsubsection{Morphology of Powder Particles}

The morphology of the powder extract particles was analyzed through Scanning Electron Microscopy (SEM). The samples were prepared by the deposition of the solids on aluminum sample holders, coated with carbon double-sided tapes, metalized with gold for 240 seconds with current of $10 \mathrm{~mA}$ in Shimadzu IC-50 metallizer, under high vacuum conditions, to promote a reflecting surface for the electron beams. Then, the samples coated with gold were observed using a SSX-550 SUPERSCAN microscope (Shimadzu, Japan), operating at $15 \mathrm{kV}$, and the morphological structures were photographed using magnifications of $50 \times, 100 \times, 500 \times$ and $1000 \times$.

\subsubsection{Fatty Acids}

For the determination of the lipid profile through gas chromatography, the lipids were extracted using the analytical methods described by the Adolfo Lutz Institute (IAL, 2008). The samples were stratified according to the ISO 5509 method (International Organization for Standardization, 1978), to determine the composition in fatty acids through gas-phase chromatography, by injecting $1 \mu \mathrm{L}$ in a gas chromatograph. The fatty acids were identified using standards of methyl esters of pure fatty acids, by comparing the retention time of the methyl esters of the samples with the standards. The fatty acids were quantified through area normalization according to Visentainer et al. (2012), expressing the result in milligrams of each acid over the total of fatty acids.

\section{Results and Discussion}

Table 1 shows the results of the analysis of total phenolics, antioxidant activity and total flavonoids of the peanut powder extracts with and without skin.

Table 1. Bioactive compounds in peanut powder extracts with and without skin

\begin{tabular}{lll}
\hline \multirow{2}{*}{ Analyses* } & \multicolumn{2}{c}{ Peanut Powder Extract } \\
\cline { 2 - 3 } & With Skin & Without Skin \\
\hline Total phenolic compounds $\left(\mathrm{mg} \mathrm{GAE} \mathrm{g}^{-1}\right)$ & $4.37 \pm 0.04$ & $2.94 \pm 0.10$ \\
Antioxidant activity-ABTS $\left(\mu \mathrm{mol} \mathrm{TEAC} \mathrm{g}^{-1}\right)$ & $5.41 \pm 0.03$ & $0.53 \pm 0.04$ \\
Total flavonoids $\left(\mathrm{mg} \mathrm{CE} \mathrm{g}^{-1}\right)$ & $0.1812 \pm 0.009$ & $0.1336 \pm 0.02$ \\
\hline
\end{tabular}

Note. ${ }^{*}$ The data are means of three replicates \pm standard deviation.

The values of total phenolic compounds were obtained from a calibration curve with gallic acid (Sigma-Aldrich), with five points (10 to $50 \mu \mathrm{g} \mathrm{mL}$ ), which showed a regression coefficient of 0.9992 . The coefficient of variation of the calibration curve varied from $1.05 \%$ to $2.10 \%$ and the total phenolic compounds varied from 4.37 to 2.94 $\mathrm{mg} \mathrm{GAE}^{-1}$. Similar results were found by Farinha (2014), studying the effect of lyophilization on the bioactive potential of extracts of kiwi pulp (1.38-9.5 $\left.\mathrm{mg} \mathrm{GAE} \mathrm{g}^{-1}\right)$ and whole kiwi (2.62-12.70 $\left.\mathrm{mg} \mathrm{GAE} \mathrm{g}^{-1}\right)$. Whent et al. (2011), in a comparative study of total phenolic compounds in raw yellow and black soybean, found values varying from 3.5 to $4.9 \mathrm{mg} \mathrm{GAE} \mathrm{g}^{-1}$, which agree with those of the present study. Malencic et al. (2012) observed a great variation of total phenolic compounds in the soybean cultivars, with contents ranging from 0.80 to $2.20 \mathrm{mg} \mathrm{GAE} \mathrm{g}^{-1}$ in yellow soybean and from 0.81 to $12.10 \mathrm{mg} \mathrm{GAE} \mathrm{g}^{-1}$ in black soybean.

The specialized literature on the subject indicates that the concentration and proportion between solvents, as well as the relationship between solvent volume and sample mass, are the most important parameters in the extraction of bioactive compounds (Ilaiyaraja et al., 2015). Different solvents have been used in these extractions and the commonly used are: water, ethanol, methanol and/or acetone, or their mixtures (Bachir Bey et al., 2014).

The powder extracts of peanuts with and without skin differ regarding the antioxidant activity evaluated through the ABTS free radical-scavenging method. Superior results were reported by Jeng et al. (2010), who evaluated three varieties of black soybean through the ABTS method and obtained antioxidant activity values in the range of 7.05 to $15.98 \mathrm{mg}$ eq. of Trolox $\mathrm{g}^{-1}$. Bolanho and Beléia (2011), evaluating the antioxidant activity of the soybean cultivar BRS 267 through the ABTS method, found content of $7.1 \mu$ moles eq. of Trolox $\mathrm{g}^{-1}$. These variations can be attributed to factors such as cultivar, extraction method and type of solvent used. 
The content of flavonoids of the peanut powder extracts was $0.1812 \mathrm{mg} \mathrm{CE} \mathrm{g}^{-1}$ (with skin) and $0.1336 \mathrm{mg} \mathrm{CE} \mathrm{g}^{-1}$ (without skin). Rezende (2012), in a comparative study on physicochemical and nutritional characteristics of yellow and black soybean, found values ranging from 0.74 to $1.75 \mathrm{mg} \mathrm{CE} \mathrm{g}^{-1}$ for raw soybean and, after soybean was cooked, the contents of flavonoids decreased to $0.34 \mathrm{mg} \mathrm{CE} \mathrm{g}^{-1}$ (yellow soybean) and $0.77 \mathrm{mg} \mathrm{CE} \mathrm{g}^{-1}$ (black soybean). The products based on black soybean may also exhibit significantly superior values of flavonoids in relation to those produced with yellow soybean. Xu and Chang (2009), evaluating soybean extract based on black soybean, found values of $0.25 \mathrm{mg} \mathrm{CE} \mathrm{g}^{-1}$, whereas the yellow soybean extract contained only half of this content. Flavonoids have aroused great interest in biotechnology due to their positive influence on human health through the contribution with their therapeutic potential and anti-inflammatory, anticancer, antiviral, antiparasitic, bactericide properties, among others, which may be more effective than conventional medicines (Tarahovsky et al., 2014).

Table 2 shows the results of the analyses of wettability, hygroscopicity, apparent density and compact density of the peanut powder extracts with and without skin obtained through lyophilization. The wettability varied from $0.0063 \mathrm{~g} \mathrm{~s}^{-1}$ (powder extract with skin) to $0.0057 \mathrm{~g} \mathrm{~s}^{-1}$ (powder extract without skin), corresponding to a difference of $9.52 \%$, respectively, which means that the time necessary for the complete disappearance of the powder from the surface of the liquid at rest changes depending on the structure of the material. This behavior can be associated with the water content of the samples, and the lower it is, the easier the penetration of water will be, increasing the power of reconstitution. Similar results were found by Endo et al. (2007), who studied powder passion fruit juice and observed reduction of wettability along the storage time, a fact related to the water absorption by the sample.

Table 2. Physical composition of the peanut powder extracts with and without skin

\begin{tabular}{lll}
\hline \multirow{2}{*}{ Analyses* } & \multicolumn{2}{c}{ Peanut Powder Extract } \\
\cline { 2 - 3 } & With Skin & Without Skin \\
\hline Wettability $\left(\mathrm{g} \mathrm{s}^{-1}\right)$ & $0.0063 \pm 0.17$ & $0.0057 \pm 0.21$ \\
Hygroscopicity (\%) & $4.8821 \pm 0.03$ & $5.3881 \pm 0.14$ \\
Apparent density $\left(\mathrm{g} \mathrm{mL}^{-1}\right)$ & $0.3063 \pm 0.02$ & $0.3146 \pm 0.01$ \\
Compact density $\left(\mathrm{g} \mathrm{mL}^{-1}\right)$ & $0.4027 \pm 0.02$ & $0.4588 \pm 0.005$ \\
Carr index $(\%)$ & $23.99 \pm 0.06$ & $31.31 \pm 0.02$ \\
Hausner ratio & $1.3164 \pm 0.03$ & $1.4537 \pm 0.009$ \\
\hline
\end{tabular}

Note. ${ }^{*}$ The data are means of three replicates \pm standard deviation.

The peanut powder extract with skin showed the best result of wettability, because, for an instantaneous powder, it is expected that the particles are wetted as fast as possible. In addition, the lyophilized product is easily rehydratable, because the microscopic pores are formed as a result of the ice crystals that sublimate during the drying process (Oikonomopoulou et al., 2011).

Studies conducted by Ferrari et al. (2012) with samples of blackberry pulp powder demonstrate that the wettability is inversely proportional to the size of the particles because larger structures have more empty spaces between them, being easily penetrated by water in comparison to particles of smaller pores, where the penetration of liquids in the matrix of the food is more difficult, which results in poor properties of reconstitution.

The peanut powder extracts exhibit hygroscopicity values ranging from $4.8821 \%$ (with skin) to $5.3881 \%$ (without skin). According to the classification of the GEA Niro Research Laboratory (2010) for whey powder, which can be applied for other dehydrated products, powders with hygroscopicity $<10 \%$ are classified as non-hygroscopic; 10.1 to $15 \%$, as slightly hygroscopic; 15.1 to $20 \%$, as hygroscopic; 20.1 to $25 \%$, as very hygroscopic; and $>25 \%$, as extremely hygroscopic. Thus, the peanut powder extracts are classified as non-hygroscopic, an aspect that is related to the microstructural characteristics of the material, promoting a longer lifetime to the product.

Superior results were observed by Oliveira et al. (2014) evaluating the hygroscopic behavior of yellow mombin powders obtained through lyophilization, which showed values of $12.93 \%$ for the pulp powder of whole yellow mombin and $8.51 \%$ for the pulp powder of yellow mombin containing $17 \%$ of maltodextrin. Anticaking agents (tricalcium phosphate) and drying adjuvants (maltodextrin) can be used for a better preservation of the product, 
promoting less hygroscopic powders, which is associated with the fact that these are materials with low hygroscopicity, which reduce the water absorption capacity of the lyophilized products.

The apparent density values determined for peanut powder extracts with and without skin were equal to $0.3063 \mathrm{~g}$ $\mathrm{mL}^{-1}$ and $0.3146 \mathrm{~g} \mathrm{~mL}^{-1}$, respectively. These results agree with Rocha et al. (2011), who studied the physical properties of powders of mixtures of fruit pulps with different lipid sources and observed density of $0.29 \mathrm{~g} \mathrm{~mL}^{-1}$. Superior results were reported by Medeiros and Lannes (2010), who studied physical properties of substitutes of cocoa powder and observed density values ranging between 0.49 and $0.69 \mathrm{~g} \mathrm{~mL}^{-1}$.

The mean values of compact density of the peanut powder extracts were $0.4027 \mathrm{~g} \mathrm{~mL}^{-1}$ (with skin) and $0.4588 \mathrm{~g}$ $\mathrm{mL}^{-1}$ (without skin). These results agree with Santhalakshmy et al. (2015) for jamun fruit powders mixed with $25 \%$ of maltodextrin, with results varying from 0.38 to $0.45 \mathrm{~g} \mathrm{~mL}^{-1}$. Superior results were reported by Lavoyer (2012), who studied the drying of green coconut in spouted bed and found density values between 0.585 and $0.627 \mathrm{~g} \mathrm{~mL}^{-1}$.

The results of the determinations of apparent and compact densities were used to calculate the Carr Index (CI) and Hausner Ratio (HR). The CI and HR provide an indirect result of the ease of the powder to flow, since the more spherical the particles, the smaller the air spaces inside the powder mixtures, thus facilitating their flow.

CI values between 15 and $20 \%$ indicate good fluidity; between 20 and $35 \%$, poor fluidity; between 35 and $45 \%$, bad fluidity; and CI $>45 \%$, very bad fluidity (Santhalakshmy et al., 2015). According to this classification, the peanut powder extracts with and without skin show poor fluidity, which can be related to the high percentage of lipids in the sample, compromising the fluidity. These results are in agreement with Caliskan and Dirim (2016), who evaluated the CI of sumac (Rhus coriaria) in powder obtained through different drying processes (lyophilization and atomization) and different concentrations of maltodextrin (20, 25 and 30\%), and observed results ranging from 15.89 to $25.02 \%$ (lyophilization) and 28.21 to $41.63 \%$ (atomization).

The results obtained for HR were 1.3164 (with skin) and 1.4537 (without skin). According to Santhalakshmy et al. (2015), powders with Hausner ratio lower than 1.2 are classified as of low cohesiveness; HR between 1.2 and 1.4, intermediate cohesiveness; and HR $>1.4$, high cohesiveness. In this context, it can be claimed that the powder extract with skin showed intermediate cohesiveness and the powder extract without skin showed high cohesiveness. Values between 1.25 and 1.5 can be improved by the addition of colloidal silicon dioxide at $0.2 \%$ (Wells, 2005). Similar results were reported by Bhusari et al. (2014), evaluating HR of tamarind powder mixed with different drying adjuvants (maltodextrin, gum arabic and whey protein concentrate), with values ranging from 1.3 to 1.5. Figures 1 and 2 show the photomicrographs obtained through SEM of the samples of peanut powder extracts with and without skin, respectively. 

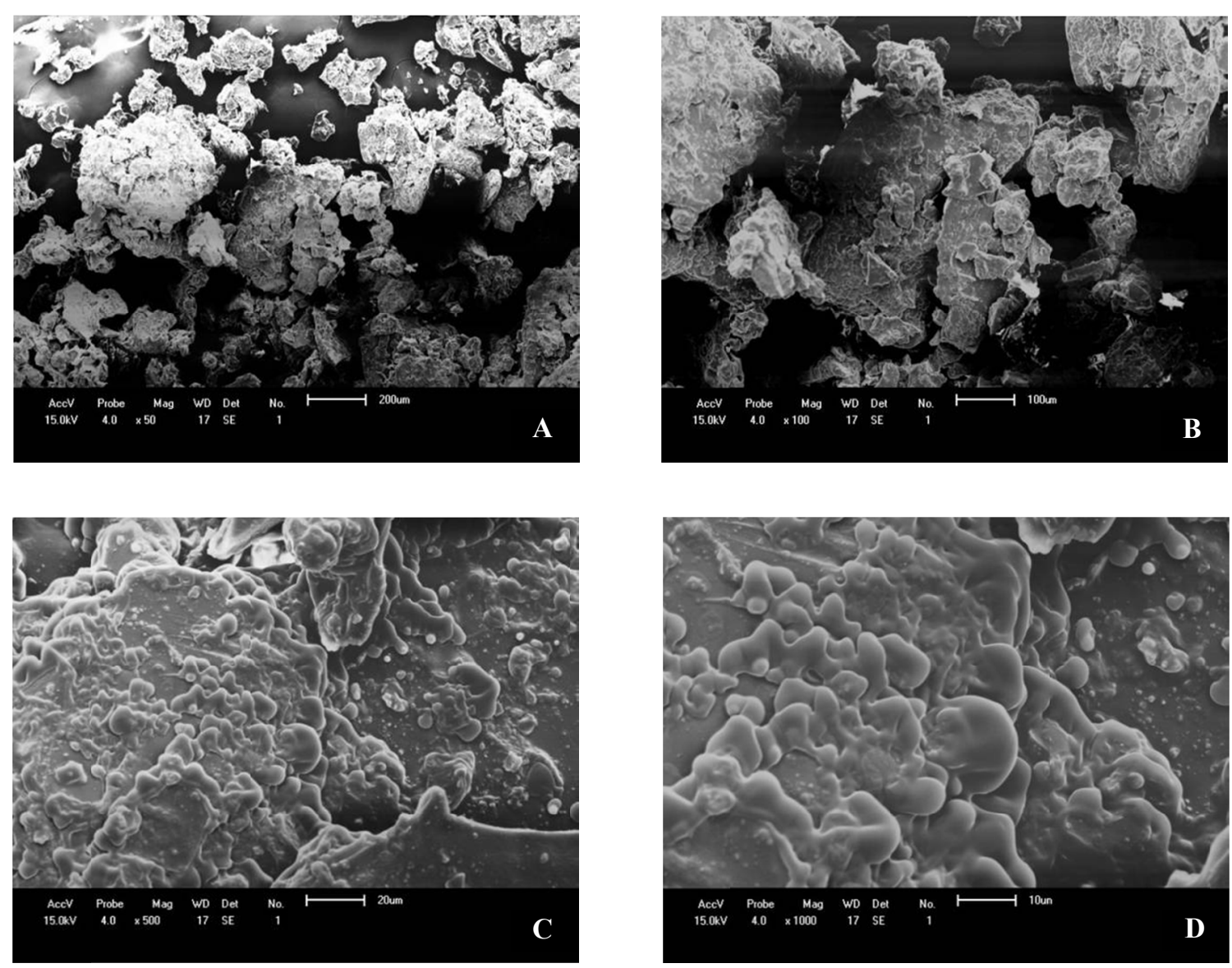

Figure 1. Photomicrographs obtained through SEM of the peanut powder extract with skin at the 1:2 proportion (peanut:water). Image magnifications of: A) 50×; B) 100×; C) 500×; D) 1000× 

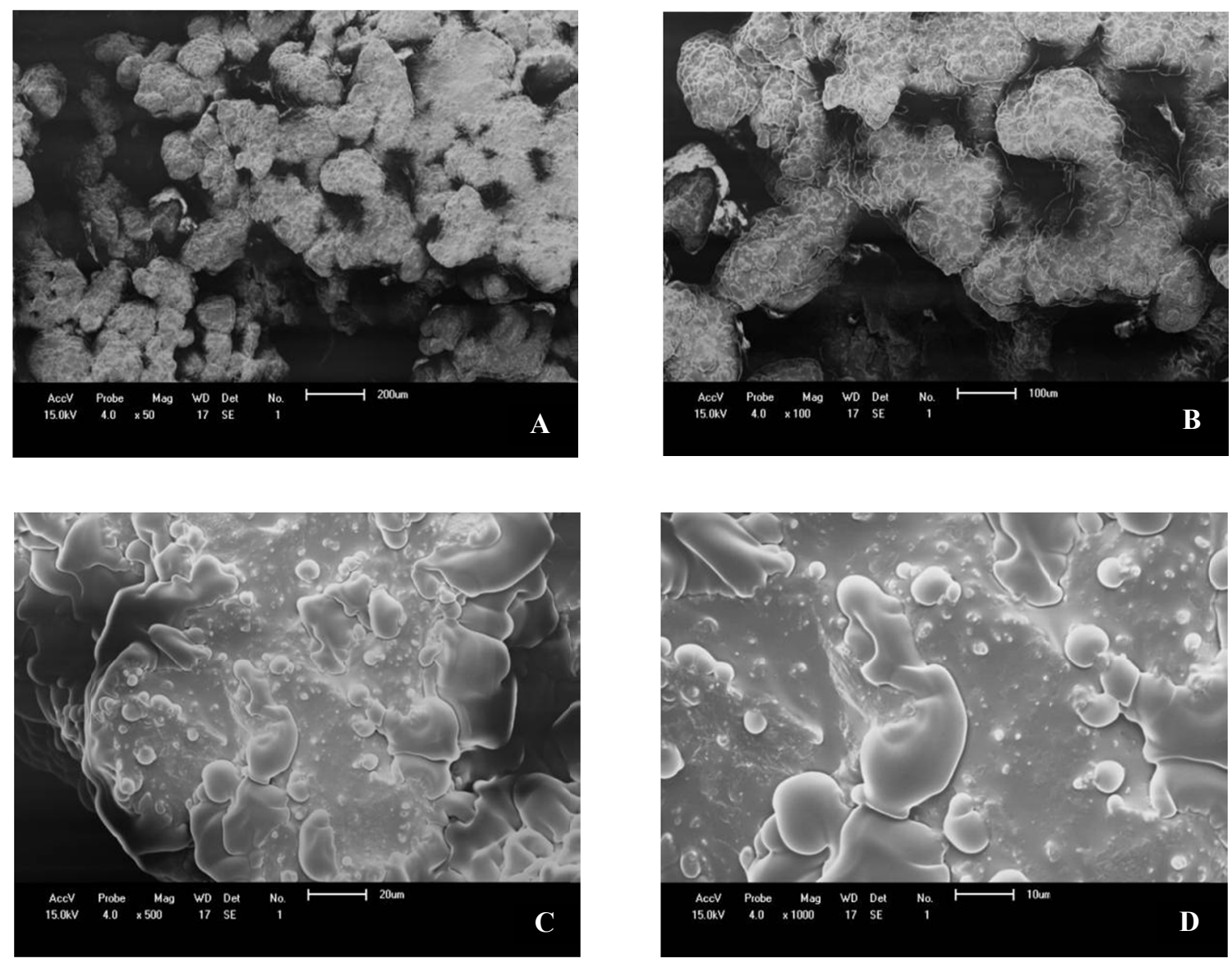

Figure 2. Photomicrographs obtained through SEM of the peanut powder extract without skin at the 1:2 proportion (peanut:water). Image magnifications of: A) $50 \times$; B) 100×; C) 500×; D) 1000×

The photomicrographs show that the obtained powders exhibit a wide particle size distribution, which is probably related to the chemical composition of the material, i.e., high percentage of lipids, forming an agglomeration of particles. The process of lyophilization without the addition of drying adjuvants also favors the non-uniformity of the particles, as well as the milling of the sample, because it is directly influenced by the water content of the powder.

The particles do not have a spherical or disperse shape. The samples showed an integrity degree with a compact distribution of the particles, demonstrating the strong presence of amorphous surfaces, i.e., characterized by a disordered state in which there is no repetition of geometric forms, common in lyophilized products. Similar results were observed by Franco et al. (2016), evaluating the morphological characteristics of yacon powders, which showed porous and irregular structures.

Different morphological characteristics were observed by Islam et al. (2016) for orange powders from the drying with different concentrations of maltodextrin, which exhibited particles with spherical shape and different sizes, a phenomenon that can be related to the drying adjuvant and temperature used in the process. Carvalho et al. (2016) studied the morphology of the powder obtained from 'juçara' extract with different concentrations of maltodextrin and observed spherical shape and irregular size of the particles.

The chromatographic profiles of the fatty acids, in the form of methyl esters, obtained from the peanut powder extracts with and without skin are presented in Table 3. 
Table 3. Fatty acid composition of the peanut powder extracts with and without skin.

\begin{tabular}{llc}
\hline \multirow{2}{*}{ Fatty acids (mg $100 \mathrm{~g}^{-1}$ of lipids) } & \multicolumn{2}{c}{ Peanut Powder Extract } \\
\cline { 2 - 3 } Saturated & With Skin & Without Skin \\
Palmitic C16:0 & $8.0000 \pm 0.024$ & $8.6203 \pm 0.023$ \\
Stearic C18:0 & $4.3346 \pm 0.010$ & $4.4486 \pm 0.002$ \\
Arachidic C20:0 & $1.2498 \pm 0.003$ & $1.2968 \pm 0.005$ \\
Beenic C22:0 & $0.6229 \pm 0.002$ & $0.6647 \pm 0.005$ \\
Monounsaturated & $1.7927 \pm 0.009$ & $2.2102 \pm 0.011$ \\
Oleic C18:1 & $26.0094 \pm 0.017$ & $28.6719 \pm 0.008$ \\
Eicosenoic C20:1 & $25.3536 \pm 0.014$ & $27.9162 \pm 0.002$ \\
Polyunsaturated & $0.6558 \pm 0.003$ & $0.7557 \pm 0.006$ \\
Linoleic C18:2 & $9.0854 \pm 0.001$ & $9.1751 \pm 0.005$ \\
\hline
\end{tabular}

Note. Values expressed in mean \pm standard deviation.

As to the composition, the powder extracts are mainly composed of the oleic (C18:1) and linoleic (C18:2) fatty acids. Martín et al. (2016), evaluating the chemical, sensory and microbiological stability of raw peanut stored in polypropylene packages, also observed that the oleic and linoleic fatty acids are present in larger amounts. This composition in mono- and polyunsaturated fatty acids is important for health, since these acids contribute to the reduction of the fractions of Low-Density Lipoprotein (LDL) and Very Low-Density Lipoprotein (VLDL), responsible for the increase in serum cholesterol. The high content of linoleic acid is nutritionally important, because it is an essential fatty acid, precursor of the other fatty acids from the Omega-6 family (Jorge and Luzia, 2012).

Among the saturated fatty acids, the palmitic acid was predominant in the oil, followed by the beenic and stearic acids. This result is coherent, because the palmitic acid is the most abundant saturated fatty acid in plant lipids, whereas the beenic and stearic acids are less common. Similar results were reported by Martín et al. (2016), who

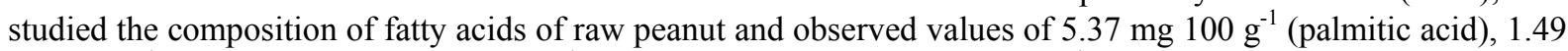

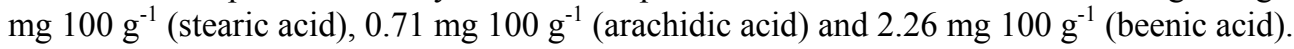

\section{Conclusions}

Based on the obtained results, it can be concluded that the bioactive compounds are found in larger amounts in the peanut powder extract with skin. The peanut powder extracts are classified as non-hygroscopic, have poor fluidity, intermediate cohesiveness in samples with skin and high cohesiveness in samples without skin. The particles of the powders exhibit a spherical shape, showing the presence of amorphous surfaces, in which there is no repetition of geometric forms. The peanut powder extracts have significant percentages of minerals $(\mathrm{K}, \mathrm{P}, \mathrm{Mg}$ and $\mathrm{Ca}$ ) and are mainly composed of oleic and linoleic fatty acids.

\section{References}

Araujo, W. D., Goneli, A. L. D., Souza, C. M. A., Gonçalves, A. A., \& Vilhasanti, H. C. B. (2014). Physical properties of peanut kernels during drying. Revista Brasileira de Engenharia Agrícola e Ambiental, 18(3), 279-286. https://doi.org/10.1590/S1415-43662014000300006

Ayala-Zavala, J. F., Vega-Vega, V., Rosas-Domínguez, C., Palafox-Carlos, H., Villa-Rodriguez, J. A., Wasim Siddiqui, M. D., ... González-Aguilar, G. A. (2011). Agro-industrial potential of exotic fruit byproducts as a source of food additives. Food Research International, 44(1), 1866-1874. http://doi.org/10.1016/j.foodres. 2011.02.021

Bachir Bey, M., Meziant, L., Benchikh, Y., \& Louaileche, H. (2014). Deployment of response surface methodology to optimize recovery of dark fresh fig (Ficus carica L., var. Azenjar) total phenolic compounds and antioxidant activity. Food Chemistry, 162(1), 277-282. https://doi.org/10.1016/j.foodchem. 2014.04.054

Bargale-Praveen, C., Irudayaraj, J., \& Marquist, B. (1995). Studies on rheological behaviour of canola and wheat. J. Agric. Engineering Research, 61, 267-274. https://doi.org/10.1006/jaer.1995.1054 
Bhusari, S. N., Muzaffar, K., \& Kumar, P. (2014). Effect of carrier agents on physical and microstructural properties ofspray dried tamarind pulp powder. Powder Technology, 266(1), 354-364. http://doi.org/ 10.1016/j.powtec.2014.06.038

Bolanho, B. C., \& Beléia, A. P. (2011). Bioactive compounds and antioxidant potential of soy products. Alimentos e Nutrição, Araraquara, 22(4), 539-546.

Caliskan, G., \& Dirim, N. S. (2016). The effect of different drying processes and the amounts of maltodextrin addition on the powder properties of sumac extract powders. Powder Technology, 287(1), 308-314. http://doi.org/10.1016/j.powtec.2015.10.019

Caparino, O. A., Tang, J., Nindo, C. I., Sablani, S. S., Powers, J. R., \& Fellman, J. K. (2012). Effect of drying methods on the physical properties and microstructures of mango (Philipine 'Carabao' var.) powder. Journal of Food Engineering, 14(1), 135-148. http://doi.org/10.1016/j.jfoodeng.2012.01.010

Carvalho, A. G. S., Machado, M. T. C., Silva, V. M., Sartoratto, A., Rodrigues, R. A. F., \& Hubinger, M. D. (2016). Physical properties and morphology of spray dried microparticles containing anthocyanins of juçara (Euterpe edulis Martius) extract. Powder Technology, 294(1), 421-428. http://doi.org/10.1016/j.powtec. 2016.03.007

De-Melo, A. A. M., Estevinho, M. L. M. F., Sattler, J. A. G., Souza, B. R., Freitas, A. S., Barth, O. M., \& Almeida-Muradian, L. B. (2016). Effect of processing conditions on characteristics of dehydrated bee-pollen and correlation between quality parameters. LWT-Food Science and Technology, 65(1), 808-815. http://doi.org/10.1016/j.lwt.2015.09.014

Endo, E., Borges, S. V., Daiuto, E. R., Cereda, M. P., \& Amorim, E. (2007). Shelf life evaluation of dehydrated passion fruit juice (Passiflora edullis f. flavicarpa). Ciência e Tecnologia de Alimentos, 27(1), $382-386$. http://doi.org/10.1590/S0101-20612007000200029

Farinha, P. M. D. (2014). Efeito da liofilização e da adição de goma arábica no potencial bioativo de extratos de morango e kiwi (86 f. Dissertação, Mestrado em Inovação e Qualidade na Produção Alimentar, Universidade Politécnica de Valência, Valência).

Ferrari, C. C., Germer, S. P. M., Alvim, I. D., Vissottto, F. Z., \& Aguirre, J. M. (2012). Influence of carrier agents on the physicochemical properties of blackberry powder produced by spray drying. International Journal of Food Science and Technology, 47(1), 1237-1245. https://doi.org/10.1111/j.1365-2621.2012.02964.x

Franco, T. S., Perussello, C. A., Ellendersen, L. N., \& Masson, M. L. (2016). Effects of foam mat drying on physicochemical and microstructural properties of yacon juice poder. LWT-Food Science and Technology, 66(1), 503-513. http://doi.org/10.1016/j.lwt.2015.11.009

Freire, J. M., Abreu, C. M. P., Corrêa, A. D., Simão, A. A., \& Santos, C. M. (2012). Evaluation of functional compounds and antioxidant activity in guava pulp flour. Revista Brasileira de Fruticultura, 34(3), 847-852. http://doi.org/10.1590/S0100-29452012000300026

GEA Niro Research Laboratory. (2010). Gea Niro analytical methods. Retrieved July, 30, 2016, form http://www.niro.com/methods

Goula, A. M., \& Adamopoulos, K. G. (2010). A new technique for spray drying orange juice concentrate. Innovative Food Science and Emerging Technologies, 11(1), 342-351. https://doi.org/10.1016/j.ifset. 2009.12.001

Hausner, H. H. (1967). Friction conditions in a mass of metal powder. Powder Metall, 3(1), 7-13.

IAL (Instituto Adolfo Lutz). (2008). Normas Analiticas do Instituto Adolfo Lutz: Métodos Químicos e Físicos para Análise de Alimentos (4th. ed., p. 1020). São Paulo: IAL.

Ilaiyaraja, N., Likhith, K. R., Sharath Babu, G. R., \& Khanum, F. (2015). Optimisation of extraction of bioactive compounds from Feronia limonia (wood apple) fruit using response surface methodology (RSM). Food Chemistry, 173(1), 348-354. https://doi.org/10.1016/j.foodchem.2014.10.035

International Organization for Standardization. (1978). EN ISO 5509: Animal and vegetable fats and oils: Preparation of methyl esters of fatty acids. London: International Organization for Standardization.

Islam, M. Z., Kitamura, Y., Yamano, Y., \& Kitamura, M. (2016). Effect of vacuum spray drying on the physicochemical properties, water sorption and glass transition phenomenon of orange juice poder. Journal of Food Engineering, 169(1), 131-140. http://doi.org/10.1016/j.jfoodeng.2015.08.024 
Jeng, T. L., Shih, Y. J., Wu, M. T., \& Sung, J. M. (2010). Comparisons of flavonoids and anti-oxidative activities in seed coat, embryonic axis and cotyledon of black soybeans. Food Chemistry, 123(1), 1112-1116. http://doi.org/10.1016/j.foodchem.2010.05.070

Jorge, N., \& Luzia, D. M. M. (2012). Characterization of seed oil Pachira aquatica Aublet for food utilization. Revista Acta Amazônica, 42(1), 149-156. https://doi.org/10.1590/S0044-59672012000100017

Juliano, F. F., Silva, P. P. M., Casemiro, R. C., Costa, M. H., \& Spoto, M. H. F. (2014). Camu-camu pulp lyophilized and stored in different packages. Revista Brasileira de Tecnologia Agroindustrial, 8(2), 1374-1384.

Lavoyer, F. C. G. (2012). Estudo da secagem de polpa de coco verde em leito de jorro e viabilidade de sua utilização na indústria (74 f. Dissertação, Mestrado em Engenharia e Ciência de Alimentos, Universidade Estadual Paulista "Júlio de Mesquita Filho", São José do Rio Preto).

Malencic, D., Cvejic, J., \& Miladinovic, J. (2012). Polyphenol content and antioxidant properties of colored soybean seeds from Central Europe. Journal of Medicinal Food, 15(1), 89-95. http://doi.org/10.1089/ jmf.2010.0329

Martín, M. P., Nepote, V., \& Grosso, N. R. (2016). Chemical, sensory, and microbiological stability of stored raw peanuts packaged in polypropylene ventilated bags and high barrier plastic bags. LWT-Food Science and Technology, 68(1), 174-182. http://doi.org/10.1016/j.lwt.2015.12.031

Medeiros, M. L., \& Lannes, S. C. S. (2010). Physical properties of cocoa substitutes. Ciência e Tecnologia de Alimentos, 30(1), 243-253. https://doi.org/10.1590/S0101-20612010000500037

Nóbrega, E. M., Oliveira, E. L., Genovese, M. I., \& Correia, R. T. P. (2014). The impact of hot air drying on the physical-chemical characteristics, bioactive compounds and antioxidant activity of acerola (Malphigia emarginata) residue. Journal of Food Processing and Preservation, 39(1), 131-141.

Oikonomopoulou, V. P., Krokida, M. K., \& Karathanos, V. T. (2011). The influence of freeze drying conditions on microstructural changes of food products. Procedia Food Science, 1(1), 647-654. https://doi.org/ 10.1016/j.profoo.2011.09.097

Oliveira, G. S., Costa, J. M. C., \& Afonso, M. R. A. (2014). Characterization and hygroscopic behavior of lyophilized yellow mombin in pulp powder. Revista Brasileira de Engenharia Agrícola e Ambiental, 18(10), 1059-1064. http://doi.org/10.1590/1807-1929/agriambi.v18n10p1059-1064

Rezende, D. F. (2012). Estudo comparativo de características fisico-químicas e nutricionais da soja preta e amarela (118 f. Dissertação, Mestrado em Ciência dos Alimentos, Faculdade de Ciências Farmacêuticas da Universidade de São Paulo, São Paulo).

Rocha, S. C. S., Souza, J. S., Alsina, O. L. S., \& Medeiros, M. F. D. (2011). Drying of tropical fruit pulps: Spouted bed process optimization as a function of pulp composition. Drying Technology, 29(1), 1587-1599. http://doi.org/10.1080/07373937.2011.585442

Rosa, G. S., \& Cougo, C. M. S. (2014). Study of the degree of decomposition of anthocyanins and carotenoids for blackberry on drying process of tunnel dryer and freeze drying. Revista de Ciências Exatas, 33(1), 72-78.

Rufino, M. S. M., Alves, R. E., Brito, E. S., Pérez-Jiménez, J., Saura-Calixto, F., \& Mancini-Filho, J. (2010). Bioactive compounds and antioxidant capacities of 18 non-traditional tropical fruits from Brazil. Food Chemistry, 121(1), 996-1002. http://doi.org/10.1016/j.foodchem.2010.01.037

Santhalakshmy, S., Bosco, S. J. D., Francis, S., \& Sabeena, M. (2015). Effect of inlet temperature on physicochemical properties of spray-dried jamun fruit juice powder. Powder Technology, 274(1), 37-43. http://doi.org/10.1016/j.powtec.2015.01.016

Silva, F. V. G., Silva, S. M., Silva, G. C., Mendonça, R. R. M. N., Alves, R. E., \& Dantas, A. L. (2012). Bioactive compounds and antioxidant activity in fruits of clone and ungrafted genotypes of yellow mombin tree. Ciência e Tecnologia de Alimentos, 32(4), 685-691.

Tarahovsky, Y. S., Kim, Y. A., Yagolnik, E. A., \& Muzafarov, E. N. (2014). Flavonoid membrane interactions: Involvement of flavonoid-metal complexes in raft signaling. Biochimica et Biophysica Acta (BBA): Biomembranes, 1838(5), 1235-1246. https://doi.org/10.1016/j.bbamem.2014.01.021

Tonon, R. V., Brabet, C., \& Hubinger, M. D. (2013). Use of spray drying for obtaining functional products with high added value from açai. Inc. Soc., Brasília, 6(2), 70-76. 
Visentainer, J. V., \& Franco, M. R. (2012). Ácidos graxos em óleos e gorduras: Identificação e quantificação (2nd ed.). Eduem, Maringá, PR.

Wells, J. (2005). Pré-formulação farmacêutica. In M. E. Aulton (Ed.), Delineamento de formas farmacêuticas (Cap. 8, pp. 124-148). Porto Alegre: Artmed.

Whent, M., Lv, J., Luthria, D. L., Kenworthy, W., \& Yu, L. (2011). Isoflavone composition and antioxidant capacity of modified-lipoxygenase soybeans grown in Maryland. Journal of Agricultural and Food Chemistry, 59(1), 12902-12909. https://doi.org/10.1021/jf203823s

Woisky, R. G., \& Salatino, A. (1998). Analysis of pró-polis: Some parameters and procedures for chemical quality control. Journal Apicultural Research, 37(2), 99-105. https://doi.org/10.1080/00218839.1998.111 00961

Xu, B., \& Chang, S. K. C. (2009). Total phenolic, phenolic acid, anthocyanin, flavan-3-ol, and flavonol profiles and antioxidant properties of pinto and black beans (Phaseolus vulgaris L.) as affected by thermal processing. Journal of Agricultural and Food Chemistry, 57(11), 4754-4764. https://doi.org/10.1021/ jf900695s

\section{Nomenclature}

ABTS: 2,2-azino-bis-(3-ethylbenzothiazolin-6-sulfonic acid) ( $\mu$ mol TEAC $\mathrm{g}^{-1}$ ); TPC: Total Phenolics Content (mg GAE ${ }^{-1}$ ); eq.: Equivalent; HR: Hausner Ratio; CI: Carr Index (\%); SEM: Scanning Electron Microscopy; GAE: Gallic Acid Equivalent; CE: Catechin Equivalent; TEAC: Trolox Equivalence Antioxidant Capacity; RH: Relative Humidity (\%).

\section{Copyrights}

Copyright for this article is retained by the author(s), with first publication rights granted to the journal.

This is an open-access article distributed under the terms and conditions of the Creative Commons Attribution license (http://creativecommons.org/licenses/by/4.0/). 